\title{
Development of a large adrenal myelolipoma in the context of long-term elevated ACTH
}

\author{
Muhammad Fahad Arshad (D) , 1,2 Vidumini T S Kaluarachchi, ${ }^{3}$ Richard Ross, ${ }^{1}$ \\ Sabapathy P Balasubramanian (iD ${ }^{4}$
}

'Department of Oncology and Metabolism, The University of Sheffield, Sheffield, UK ${ }^{2}$ Department of Endocrinology and Diabetes, Sheffield Teaching Hospitals, Sheffield, UK ${ }^{3}$ District General Hospital, Gampaha, Sri Lanka ${ }^{4}$ Department of Endocrine Surgery, Sheffield Teaching Hospitals, Sheffield, UK

\section{Correspondence to} Dr Muhammad Fahad Arshad; dr.fahadarshad@live.com

Accepted 16 December 2020

Check for updates

(C) BMJ Publishing Group Limited 2021. No commercial re-use. See rights and permissions. Published by BMJ.

\begin{tabular}{|l|}
\hline To cite: Arshad MF, \\
Kaluarachchi VTS, \\
Ross R, et al. BMJ Case \\
Rep 2021;14:e240493. \\
doi:10.1136/bcr-2020- \\
240493 \\
\hline
\end{tabular}

\section{DESCRIPTION}

Adrenal myelolipomas are the second most common benign tumours of the adrenal gland. Despite their frequent occurrence, there is uncertainty around their aetiology. We present the case of a giant adrenal myelolipoma that supports the role of prolonged adrenocorticotrophic hormone (ACTH) stimulation in the induction of myelolipomas in congenital adrenal hyperplasia (CAH).

A 27-year-old man with salt-losing $\mathrm{CAH}$ due to 21 hydroxylase deficiency was initially reviewed in the endocrine department in 1996 . He was taking a total of $0.75 \mathrm{mg}$ of dexamethasone daily $-0.5 \mathrm{mg}$ in the morning and $0.25 \mathrm{mg}$ at night. He clinically appeared cushingoid with abdominal striae, centripetal obesity and hypertension. A CT scan at that time showed normal adrenal glands (figure 1, panel B). Dexamethasone was switched to prednisolone and then later to hydrocortisone to reduce the side effects of excess glucocorticoid exposure. As a consequence, his ACTH and 17-hydroxyprogesterone (17-OHP) levels were persistently elevated from the age of 27 years to the present day.

In 2018, at the age of 50 years, he presented to the emergency department with severe abdominal pain and a CT scan revealed a $15 \times 16 \times 19 \mathrm{~cm}$ mass in the left adrenal gland. Radiology review reported features of a giant adrenal myelolipoma (panel A). At this time, his morning plasma ACTH was high at $486 \mathrm{ng} / \mathrm{L}$ (reference range 7.2-63.3) and 17-OHP levels were $3337 \mathrm{ng} / \mathrm{dL}$ (reference range $<198 \mathrm{ng} / \mathrm{dL}$ ). He underwent laparoscopic excision of $2030 \mathrm{~g}$ adrenal myelolipoma (macroscopic and microscopic appearances shown in panels $C$ and D).

Adrenal myelolipomas consist of fat and haematopoietic tissues and are hormonally inactive. They are usually asymptomatic but can present with abdominal pain, spontaneous rupture and retroperitoneal haemorrhage. There are no guidelines for treatment but for large, rapidly growing tumours and those with compressive symptoms, surgery is considered. Up to $86 \%$ of myelolipomas are detected incidentally on imaging, ${ }^{1}$ and the incidence is expected to rise with the increased use of abdominal imaging in clinical practice.

The aetiology of myelolipomas is not established, but the increased incidence in patients with $\mathrm{CAH}$ and Cushing's disease, both of whom have raised ACTH levels, has suggested a role for prolonged ACTH stimulation. ${ }^{1}$ The role of hormones in inducing adrenal tumours was first proposed by Selye and Stone in 1950 who was able to induce bone marrow tissue like changes by injecting anterior pituitary hormone

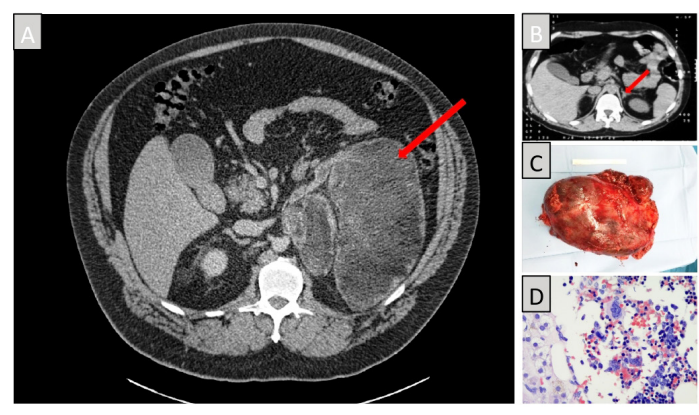

Figure 1 (A) CT scan of abdomen (2018) showing left giant adrenal myelolipoma (arrow), (B) CT scan (1996) of abdomen showing normal left adrenal gland (arrow), (C) macroscopic appearance of tumour and (D) histology of left adrenal cortex showing fat and haematopoietic tissue.

\section{Learning points}

Adrenal myelolipomas are the second most common benign tumours of the adrenal gland, and their incidence is expected to rise with the increased use of abdominal imaging in clinical practice.

- Adrenocorticotrophic hormone may play an important role in induction of these tumours.

extracts into normal rat adrenal glands. ${ }^{2}$ The increased expression of Melanocortin two receptor (MC2R) on adrenal myelolipomas further supports the role of ACTH. ${ }^{3}$ Prolonged exposure to high ACTH levels for over two decades in association with a large myelolipoma in this patient provides further evidence for the role of ACTH in the induction of myelolipomas.

Contributors Concept: RR. Collection of images: VTSK. Literature search: MFA. Writing manuscript: MFA and RR. Revision of manuscript: RR and SPB.

Funding The authors have not declared a specific grant for this research from any funding agency in the public, commercial or not-for-profit sectors.

Competing interests None declared.

Patient consent for publication Obtained.

Provenance and peer review Not commissioned; externally peer reviewed.

ORCID iDs

Muhammad Fahad Arshad http://orcid.org/0000-0001-9932-0941 


\section{Images in...}

Sabapathy P Balasubramanian http://orcid.org/0000-0001-5953-2843

\section{REFERENCES}

1 Hamidi O, Raman R, Lazik N, et al. Clinical course of adrenal myelolipoma: a long-term longitudinal follow-up study. Clin Endocrinol 2020;93:11-18.
2 Selye $\mathrm{H}$, Stone $\mathrm{H}$. Hormonally induced transformation of adrenal into myeloid tissue. Am J Pathol 1950;26:211-33.

3 Almeida MQ, Kaupert LC, Brito LP, et al. Increased expression of ACTH (MC2R) and androgen (AR) receptors in giant bilateral myelolipomas from patients with congenital adrenal hyperplasia. BMC Endocr Disord 2014;14:42.

Copyright 2021 BMJ Publishing Group. All rights reserved. For permission to reuse any of this content visit

https://www.bmj.com/company/products-services/rights-and-licensing/permissions/

BMJ Case Report Fellows may re-use this article for personal use and teaching without any further permission.

Become a Fellow of BMJ Case Reports today and you can:

- Submit as many cases as you like

Enjoy fast sympathetic peer review and rapid publication of accepted articles

- Access all the published articles

Re-use any of the published material for personal use and teaching without further permission

\section{Customer Service}

If you have any further queries about your subscription, please contact our customer services team on +44 (0) 2071111105 or via email at support@bmj.com.

Visit casereports.bmj.com for more articles like this and to become a Fellow 